\title{
THE ATTITUDE OF GENERATION Y STUDENTS TO THEIR JOINT STUDY PROGRAMME. QUALITY ASSESSMENT \\ Gita Statnicke $\dot{\mathbf{e}}^{1}$
}

\begin{abstract}
Students from Generation Y are already studying or choosing a profession, and their choice is mainly determined by their lifestyle, as they seek jobs which provide joy and are not just a source of money. Generation Y put great demands on the quality of their chosen study programme. The purpose of this research is to reveal how the joint study programme students who belong to Generation Y assess their experience in terms of quality of their studies as a service. The article discusses the concept of quality of studies as a service; provides the theoretical aspects of the study service quality assessment in a higher education institution; presents a carried out experienced quality assessment on a joint study programme as a service from the point of view of the Generation Y students; and provides recommendations for improving the quality of studies as a service from the point of view of the Generation Y students.
\end{abstract}

UDC Classification: 005, 378; DOI: http://dx.doi.org/10.12955/cbup.v6.1249

Keywords: generation, Generation Y, joint study programme, quality of studies.

\section{Introduction}

The representatives of Generation $\mathrm{Y}$ are the first generation brought up in the digital times, acquiring excellent knowledge of new technologies, speaking several foreign languages, and travelling freely around the world. It has been forecasted that by 2025 , approximately 75 per cent of the workforce will include representatives from Generation Y. At present, this generation is already studying or choosing a profession, and their choice is mainly determined by their lifestyle, as they are seeking for jobs which provide joy and are not just a source of income. Generation Y put great demands on the quality of their chosen study programme, and therefore, standard study programmes do not meet the expectations of this generation. Students from Generation $\mathrm{Y}$ have shown interest in joint study programmes - this is the European phenomenon that has received great attention in the Bologna Process.

Higher education has been acknowledged as one of the main driving forces of the "Europe 2020" strategy, capable of overcoming the social and economic crisis, stimulating countries' growth, employment and integration of citizens. The European Commission promotes cooperation between higher education institutions, with particular attention to the joint study programmes, which are organized and implemented inside the country by several higher education institutions as well as by several universities abroad. The Ministry of Education and Science of the Republic of Lithuania specifies that by studying in a joint study programme, students have an opportunity to acquire more knowledge and skills than a study programme implemented by a single institution could provide. A joint study programme with a foreign higher education institution enables students from different countries to study together in different cultural and academic environments, promotes the mobility of students and teachers, enables students to take over the study experience of different countries or higher education institutions, and this is what is aimed at by the representatives of Generation Y.

The purpose of the research is to reveal how joint study programme students who belong to Generation Y assess the experienced quality of studies as a service, by applying a seven-dimensional assessment of studies as a service: reliability, responsiveness, competence, communication, security, understanding the student and tangibility.

\section{Theoretical Aspects}

\section{Generation Y and their Attitude to Studies}

Generation $\mathrm{Y}$ is a generational demographic cohort following Generation X. Generation Y includes people who were born between 1982 and 2004 (Howe \& Strauss, 2000), and it is becoming the nation's largest living generation (Fry, 2015; Hosek \& Titsworth, 2016). The major part of present day students are representatives of Generation Y. Generation Y (also known as the Millennial Generation) is described as a generation that has grown in the context of new globalization, communication technologies and wireless communications. This generation lives in times of unprecedented diversity and the influence of different cultures. According to Taylor (2014), Generation Y is very self-

\footnotetext{
${ }^{1}$ Kaunas University of Technology, Lithuania; Klaipeda State University of Applied Sciences, Lithuania. gita.statnicke@ktu.edu, g.statnicke@kvk.lt
} 
confident and self-reliant, tending to overestimate themselves as unique individuals, they are mostly self-centred, value study/ work and life balance, and are good at acquiring and using different technologies both in their studies and other activities. Stanišauskienè (2015) points out that the representatives of Generation Y, while growing up, constantly experience excessive exposure to media and entertainment, and therefore, they have difficulties to perform mundane, patience and diligence requiring tasks. They cannot focus for longer periods of time on one thing, and become bored quickly; in addition, they raise self-realizations above studies / work. The representatives of this generation prefer online communication, make virtual social contacts, but their actual social contact network is much smaller than that of their parents or grandparents. Generation Y can be described as a generation seeking fast results, recognition, evaluation and reward. According to Raines (2002), Generation Y is frequently described as well-educated. Due to the fact that Generation Y grew up in a period of rapidly developing technologies, they demonstrate reduced tolerance to the style of lectures and provision of information (Prensky, 2001). Scholars agree that the study process should include not only active learning strategies (Roehl, Reddy, Shannon, 2013), but also the revision of study programmes as well as joining of them.

The Theoretical Definition of a Joint Study Programme

The goal of the European Union in the field of higher education is an attempt to become a place of study attraction for international youth. To achieve this goal, one of the mostly used measures is preparation and implementation of joint study programmes (Aerden \& Reczulska, 2013). The Lisbon Recognition Convention defines a study programme as "a higher education curriculum leading to a degree. It has co-ordinated elements (courses). The completion of a programme provides the student with a higher education qualification." (Council, 1997). Although, the term joint study programme is used quite often, it is not clearly defined. The European University Association's Guidelines for Quality Enhancement in European Joint Master Programmes refers to joint programmes as "programmes which are developed and implemented jointly by several institutions in different countries." (d'Egmont, 2006). Based on the data of the Ministry of Education and Science of the Republic of Lithuania (2018), a joint study programme is a study programme that is jointly prepared by at least two higher education institutions. Students of Generation Y, when studying in a joint study programme, have a chance to acquire more knowledge and skills than could be provided by a study programme provided by a single institution. Generation Y students find a joint study programme with a foreign higher education institution even more attractive, as it provides them with a possibility to study among students from different cultural and academic backgrounds, enhances the mobility of students and teachers, and enables students to take over the study experience of different countries or higher education institutions.

The Concept of Quality of Studies as a Service

Higher education is one of the most important conditions of successful development of a state, and therefore, a modern university faces very high requirements in the context of the quality of studies (Bobrova, Grajauskas \& Norkus, 2010). According to Pukelytė (2010), higher education institutions have first been treated as service providing organizations by the representatives of global quality management. The theory of service quality management allows the grounding of education services as a process, the content and process of which are safeguarded by the consumer needs, expectations and a possibility of mutual agreement between the service provider and the user as far as the quality of service is concerned (Trakšelys \& Martišauskienè, 2016).

The research "The Quality of Studies: the Stakeholders' Approach", carried out in 2014 and commissioned by the Research and Higher Education Monitoring and Analysis Centre (MOSTA), suggests that 1) "there is no agreement on the uniform definition of the quality of studies, this concept is dynamic, multi-dimensional and multi-level"; 2) the contemporary society sees the quality of studies as highly dependent on specific things: the level of management of a higher education institution, the modernity of study programmes, the professionalism of the academic staff who provide the most up to date scientific knowledge, the international exchange of teachers and students, the transparency of the motivational system of the academic community, etc. Žibènienè \& Dudaite (2012) distinguish the most popular contemporary concepts of quality: 1) quality as improvement - the emphasis is on the aspect of continuous improvement; 2) quality as perfection - seeking for the best; 3) quality as "lack of errors" - standards and standardized units of measurement can precisely indicate whether the 
product meets standards or not; 4) quality as a change - the focus is on the learner; 5) quality as a means to determine certain norms and criteria; 6) quality as "goal matching" - the application of quality must be specific: quality for a specific purpose; 7) quality as effective management and communication, staff stability.

The quality of studies as a service is regulated by international documents (the European Standards and Guidelines for Quality Assurance, 3rd edition, the provisions of the European Higher Education Area, formulated in the Bologna Process, study programmes are harmonized with the European Union directives, etc.); the national legislation (e.g. the Law on Higher Education and Research of the Republic of Lithuania, the Description of Lithuanian Qualification Framework Standard, the Descriptor of Study Cycles, etc.); strategic documents of each higher education institution (e.g. the Statute, the Guidelines of Strategic Development, etc.), and provisions and procedures (e.g. the Provisions of Study Quality Assurance, the Provisions of Study Programme Committees, the Procedure of Study Programme Preparation, Improvement and Management, the Study Regulation, etc.).

Scientific literature still continues to debate whether a student can indeed be treated as one of the clients of a study service provided by a university, and if not, whether the university studies can be treated as a service (Pukelyte, 2010). Students' approach is an important factor in all the initiatives of higher education culture improvement as well as in the study quality assurance systems. The involvement of students in the management of a higher education system allows a more adequate view of the study process and the related issues (Toleikis \& Butvilas, 2014). Milišiunnaitè et al. (2011) emphasize the importance of quality as a change, because a student is an active participant of the learning process, responsible for his / her learning, meanwhile a teacher is not only the one who is teaching, but also the one who is learning (Žibènienè \& Dudaitè, 2012).

Pukelyte (2010), referring to Ali \& Zairi (2009), points out that higher education studies are treated as a service because of a clear service provider and user; they are characterized by the same features as all other services; in addition, the quality of studies as a service is highlighted in the activities of all higher education institutions as one of the key indicators declared by universities. In general, the basis of the quality of studies in universities includes the following components: high quality study programmes; the subject-specific and pedagogical competence of the academic staff; the study process meeting the needs of students.

Study Quality Assurance and Assessment

The quality of studies is a key element of the strategic goals of each higher education institution (Norvilienè, 2015). Although Žibènienė \& Targamadzè (2006) point out that much attention is being paid to the issue of higher education study quality assurance, the quality assessment of university studies, and the parameters of the study quality assessment system (Campbell \& Marijk van der Wende, 2000; Čižas, 1996, 2001; Dienys, Pukelis \& Žiliukas, 2005; Pukelis \& Pileičikienè, 2005; Stumbrys, 2003; Savickienė, 2005; Valiuškevičiūtè, Druskytė \& Mikutavičienė, 2003), nevertheless, according to Pukelyte (2010), there are no common quality assessment dimensions and criteria. It is more difficult to evaluate university studies as a service, and thus it is difficult to imagine the quality improvement of university studies as a service. Quality in a higher education institution is first and foremost understood as the quality of studies, which is an integral part of the organization of studies, the subject-specific qualification expression of the academic staff as well as teaching and study measures, determining the delivery of study subjects / modules, the organization of the study process, the interaction between teachers and students. However, the concept of quality covers a much wider scope of activities implemented by the university community - scientific research, clinical licenced activities and decision-making as well as university administration. The Dictionary of Higher Education Terms (2012) states that study quality assurance is a periodic self-evaluation and assessment of a study subject, module, programme or institution (department), while the obtained results enable the improvement of the quality of studies.

Based on the Bologna Process documents, study quality assurance in higher education covers a wide scope of activities and is not limited to the improvement of the quality of studies. This is a much wider concept which encompasses the institutional management of a higher education institution, the community-based understanding of the quality assumption, the strategic improvement and quality of 
the research staff and the academic staff, financial, material resources, and involvement of stakeholder groups interested in studies as well as their assessment and improvement. The majority of Lithuanian higher education schools in this context have already found their way or are actively pursuing for study quality assurance in higher education (Baranauskiené, Bukauskiené \& Valaikiené, 2011). According to the Law on Higher Education and Research of the Republic of Lithuania (2016), research and study quality assurance is ensured through internal quality assurance systems, external assessment and accreditation of study programmes, external research assessments, and external assessment and / or accreditation of research and study institutions. The Centre for Quality Assessment in Higher Education, through its external assessment and accreditation, promotes the quality of performance in higher education institutions and, through foreign qualification assessment and recognition as well as provision of information, creates favourable conditions for the free mobility of people.

It is important to mention that the quality of services can be assessed only if the service was used. The quality of studies is assessed in two ways: externally (the main features - the assessment of study programmes and the institution) and internally (this is a quality system created by the higher education institution and is continuously improved) (Norviliene, 2015). Thus, it is imperative to distinguish the dimensions and criteria of assessment. According to Žibènienè \& Targamadzė (2006), the criterion of the study programme quality assessment is an indicator on the basis of which the quality of a study programme can be determined. There are many models of service quality assessment, thus they can be grouped based on the type of research. The following groups of service assessment models can be distinguished: a) consumer perception quality models; b) service provision process models; c) service provision system models (Bagdoniene \& Hopeniené, 2005). To assess the quality of services, different models are used: the model of total perceived quality (Gronroos, 2000), the 4Q model of quality (Gummesson, 1993), the integrated quality model of Gummesson \& Gronroos, the extended 4Q model of quality (Gummesson, 1993), the service quality model (Parasuraman, Zeithalm \& Berry, 1985), the quality model of Meyer and Mattmuller (Langer, 1997), the quality model of Servgual (Parasuraman, Zeithalm \& Berry, 1988), etc., which allow the verification of theoretical knowledge in practice (Kinderis, Žalys \& Žalienè, 2011).

Many scholars point out that the quality of service is best understood by the customer when comparing the expected quality of service with the received (experienced) quality of service (Grönroos, 1990; Vengrienè, 2006). The model of total perceived quality suggests that the total perceived quality of service is determined by the expected and the experienced quality. The expected quality is the function of several factors, while the experienced quality aspects (technical and functional) reflect the quality of the result and the process. It was noticed that researchers (Stodnic \& Rogers 2008; Tan \& Kek, 2004; Douglas, McClelland \& Davies 2008; Abdullah, 2005, 2006), carrying out research of the quality assessment of studies as a service, use the service quality assessment dimensions empirically grounded by Parasuraman, Zeithalm \& Berry $(1985,1991)$ (Sajienè \& Tamuliené, 2011). Although in modern scientific literature, the five-dimensional service quality assessment model is widely applied. Pukelyte (2010) distinguishes seven dimensions of the assessment of the quality of studies as a service, based on Prugsamatz, Heaney \& Atpert (2007) and the quality model of Servqual (Parasuraman, Zeithalm \& Berry, 1988): reliability, responsiveness, competence, communication, security, understanding the student and tangibility. According to Norviliene (2015), the study process quality assessment is relevant and valuable when renewing study programmes, and foreseeing further possibilities of improvement of the study process. In the student-centred study model, a student is understood as an active participant of the study process, and therefore, his / her participation in the quality assessment is necessary and important. It is also necessary to emphasize that the harmonization of higher education studies and their quality assurance must be closely linked to the higher education quality management (Žibènienė \& Targamadzè, 2006).

To sum up, we can assume that the quality of studies in higher education is assessed in two ways: external and internal. The main evaluator of the services provided by a higher education institution is a student. When performing quality assessment of studies as a service, the application of a sevendimensional quality assessment is most appropriate. 


\section{Data and Methodology}

Quantitative research was carried out on 10 January - 23 February 2018, applying a written questionnaire method. The questionnaire was prepared by using seven dimensions and criteria for the quality assessment of studies as a service (Prugsamatz, Heaney \& Atpert, 2007; Pukelyte், 2010) and the quality model of Servqual (Parasuraman, Zeithalm \& Berry, 1988), i.e. students of joint study programmes who belong to Generation $\mathrm{Y}$, assessed their experienced quality of studies, evaluating reliability, responsiveness, competence, communication, security, understanding the student and tangibility, using the Likert scale from 1 (very poor evaluation of the criterion of the study quality dimension) to 5 (very good evaluation of the criterion of the study quality dimension). The questionnaire includes three parts: Section A - the demographic data, Section B - the 7 dimensions and criteria of quality assessment of studies as a service; Section $\mathrm{C}$ - the suggestions of joint study programme students on how to improve the quality of studies.

The sample of the participants of the quantitative research is related to the number of students in five joint study programmes of Lithuania, who belong to Generation Y. The fact of belonging to the Generation $\mathrm{Y}$ is determined by the date of birth. The research included 78 students of joint study programmes (the representatives of Generation Y) from 5 higher education institutions of Lithuania from the first to the third year. The distribution of respondents by gender is as follows: 41.03 per cent $(n=32)$ were male and 58.97 per cent $(n=46)$ were female. The average age of the participants of the research belonging to Generation $\mathrm{Y}$ and studying in joint study programmes is 20.92 .

The data analysis was performed using the SPSS 15.0 program, determining the characteristics of the numerical sample and performing the analysis of the mean differences of the criteria of the service quality assessment dimensions.

\section{Results and Discussion}

The research participants, who belong to Generation $\mathrm{Y}$ and study in joint study programmes in higher education institutions of Lithuania, in the service quality reliability dimension gave the lowest evaluation to the criterion Administrative staff timely informs students about the changes in the study procedure - the mean is 3.65 points, while the highest evaluation was given to the criterion When evaluating students' works, teachers are right and impartial - the mean is 4.27 points. Due to the fact that Generation $\mathrm{Y}$ is self-centred and appreciates direct contact directed towards themselves, the current non-personal communication of the administrative staff with a group, rather than with each student individually, needs to be changed by personalizing the entire communication process, while also reviewing the means of communication (e.g. Generation Y tends to commutate on social networks, rather than using emails), this would ensure that each joint study programme student receives timely information about the changes in the study procedure. When evaluating the service quality responsiveness dimension, the joint study programme students, belonging to Generation Y, gave the lowest evaluation to the criterion If the student's questions cannot be answered promptly, a reason is indicated - the mean is 3.87 points, while the highest evaluation was given to the criterion All the questions of students are solved following the procedure established at the university - the mean is 4.37 points. The lowest evaluation of the responsiveness dimension criterion, likewise in the case of the reliability dimension, reveals the necessity of reviewing and personalizing communication with Generation Y. In the service quality competence dimension, the lowest evaluation was given to the criterion Teachers have the ability to raise students' interest in the subject they are delivering - the mean is 3.96 points, while the highest evaluation was given to the criterion Teachers are good experts in the subject they deliver - the means is 4.35 points. The assessment of the criteria of the competence dimension revealed a paradox: although teachers are evaluated as experts of their own subject, nevertheless their ability to raise interest in the subject in the students, who belong to Generation $\mathrm{Y}$ are given the lowest evaluation. One of the reasons might be that the study methods used by the academic staff are not adapted to Generation Y, who are able to easily use modern technologies (Howe, Strauss, 2009), but unable to focus on one subject for a longer time, getting bored quickly (Zhao, 2007), preferring professional and social mobility, and seeking for a creative, interactive and joyful study process (Eckleberry-Hunt, Tucciarone, 2011). Speaking of the service quality communication dimension, joint study programme students of Generation $\mathrm{Y}$ indicated that a student is respected (first of all as a person) (the mean is 4.15 points), while the lowest evaluation is given to the criterion Students are given personal attention - the mean is 3.85 points. As in the case of evaluation of the 
dimensions of reliability and responsiveness, students of Generation Y lack personal attention. When evaluating the service quality security dimension, joint study programme students of Generation Y gave the lowest evaluation to the criterion I feel financially secure studying at the university - the mean is 3.98 points, while the highest evaluation was given to the criterion Conditions are created to correct the completed work or retake (repeat) the course delivered, in case it was not properly acquired - the mean is 4.25 points. One of the factors, adding to the lack of financial insecurity is the specifics of a joint study programme: due to the fact that such a study programme is jointly prepared and implemented by at least two higher education institutions, and is often jointly implemented together with a foreign higher education institution, additional resources are needed in order to study in different cultural and academic environments, where student mobility of Generation $\mathrm{Y}$ is required. In the service quality dimension of understanding the student, the lowest evaluation is given to the criterion Teachers know individual study needs of each student - the mean is 3.67 points, while the criterion given the highest evaluation is Teachers know students' needs with respect to the subject studied - the mean is 3.85 points. Due to the fact that the representatives of Generation Y grew constantly staying in the centre of attention, thus in the study process they tend to meet their individual needs for studying. Evaluating the quality tangibility dimension of a joint study programme as a service, the lowest evaluation is given to the criterion Good living conditions in dormitories - the mean is 3.73 points; while the highest evaluation is given to the criterion Classes, laboratories and libraries are equipped up-to-date - the mean is 4.52 points. Although higher education institutions implementing joint study programmes pay much attention to the improvement of the environment of studies, nevertheless good living conditions in dormitories should also be ensured if possible: Generation Y grew up in a period of overall abundance, often much better provided financially than the representatives of the generations preceding Generation $\mathrm{Y}$, and therefore when living in dormitories they expect good living conditions.

Summing up the overall evaluation of each of the quality assessment dimensions of the joint study programme as a service, students of Generation $\mathrm{Y}$ gave the highest evaluation to the dimensions of tangibility and security (the overall mean is 4.12 points), while the lowest evaluation was given to the dimensions of understanding the student (the overall mean is 3.76 points) and communication (the overall mean is 3.98 points). Characteristics of Generation $\mathrm{Y}$ have shaped as a response to the challenges of the times, and their expectations are completely different from those of Generation $\mathrm{X}$, the Baby Boomers or the Silent Generation; they want constant communication. Generation Y expect constant feedback and feel left to their own devices if the administration and / or the academic staff of a higher education institution cannot ensure constant regular communication. Generation Y experiences the greatest stress factor in the study process if they lack attention and individual communication.

\section{Conclusion}

Having discussed the concept of study service quality in a higher education institution, it was found that studies in a higher education institution can be treated as a service, because there is a clearly identifiable service provider and user; they are characterized by the same features likewise all other services (intangibility, heterogeneity, inseparability, aging); in addition, the quality of studies as a service is emphasised in the activities of all higher education institutions.

Study quality assurance is a periodic self-evaluation and assessment of a study subject, module, programme or institution (department), while the obtained results enable the improvement of the quality of studies. The quality of studies in a higher education institution is assessed in two ways: external and internal. One of the main evaluators of the services provided by a higher education institution is a student. When performing quality assessment of studies as a service, the sevendimensional quality assessment of studies as a service is most appropriate: reliability, responsiveness, competence, communication, security, understanding the student and tangibility.

Students of the Generation Y who study in joint study programmes of higher education institutions of Lithuania gave the highest evaluation to the service quality dimensions of tangibility and security, while the lowest evaluation is given to the dimensions of understanding the student and communication. The representatives of the Generation Y grew up constantly staying in the centre of attention, thus in the study process they tend to meet their individual needs for studying. The research showed that students of the Generation Y lack individual attention, and therefore, the entire 
communication process needs to be changed in order to get to better know the students of the Generation $\mathrm{Y}$ and to personalize communication with the representatives of this generation. Although a joint study programme enables students from different countries to study together in different cultural and academic environments, promotes the mobility of students and teachers, enables students to take over the study experience of different countries or higher education institutions and to play an active role in the study process, however, this is not enough. At the same time, it is necessary to review the means of communication as well as the study methods applied by the academic staff, which are not adapted to Generation $\mathrm{Y}$ who are able to easily use modern technologies, but unable to focus for a longer time on one subject, quickly getting bored, preferring professional and social mobility.

Students of Generation Y provided the following quality improvement guidelines for a joint study programme as a service: more efficient communication, cooperation and sharing of information between both universities; information synchronization and easy accessibility for students via the common information system; more efficient adjustment of the study process / timetables in the beginning of a semester; and more related and integrated modules of both universities.

\section{References}

Aerden, A., \& Reczulska, H. (2012). Guidelines for good practice for awarding joint degrees. ECA Occasional Paper, ECA, The Hague www. ecaconsortium. net.

Bagdonienè, L., \& Hopenienė, R. (2004). Paslaugų marketingas ir vadyba (= Service Marketing and Management). Kaunas: Technologija, 468.

Baranauskienè, I., Bukauskienė, V., \& Valaikienė, A. (2011). Aukštojo mokslo studijų kokybės užtikrinimo vertinimas studentų požiūriu (= Assessment of Quality Assurance in Studies of Higher Education from the Students' Point of View) Pedagogika, 102, 16-24.

Bobrova, L., Grajauskas, L., \& Norkus, S. (2010). Kūno kultūros specialybės universitetinių studijų kokybės vertinimas: studentų nuomonė (= Assessment of Quality of University Studies of Physical Education: Students' Opinion). Mokytojų ugdymas, (15), 162-176.

Council, O.E. (1997). Convention on the recognition of qualifications concerning higher Education in the European region. The European Treaty Series, (165).

d'Egmont, R. (2006). Guidelines for quality enhancement in European Joint Master programmes.

Eckleberry-Hunt, J., \& Tucciarone, J. (2011). The challenges and opportunities of teaching "Generation Y". Journal of graduate medical education, 3(4), 458-461.

Fry, R. (2015). Millennials surpass Gen Xers as the largest generation in US labor force. Pew Research Center, 11.

Hosek, A. M., \& Titsworth, S. (2016). Scripting knowledge and experiences for millennial students. Communication Education, 65(3), 357-359.

Howe, N., \& Strauss, W. (2009). Millennials rising: The next great generation. Vintage.

Howe, N., \& Strauss, W. (2009). Millennials rising: The next great generation. Vintage.

Kinderis, R., Žalys, L., \& Žalienė, I. (2011). Paslaugų kokybės vertinimas viešbučių versle (= Evaluation of Service Quality in Hotel Business). Ekonomika ir vadyba: aktualijos ir perspektyvos: collection of scientific articles, (1), 86-100.

Norvilienè, A. (2015). Studijų proceso kokybès vertinimas aukštojoje mokykloje: studentų nuomonè (= The Evaluation of Quality of the Study Process in Higher Education: Opinion of Students). Studies in Modern Society, 6(1).

Pukelyte, R. (2010). Universitetinių studijų kaip paslaugos kokybės vertinimas: dimensijos ir kriterijai (= Quality Assessment of University Studies as a Service). Aukštojo mokslo kokybè, 2010, No. 7, p. 155-175.

Raines, C. (2002). Managing millennials. Connecting Generations: The Sourcebook, 16.

Research and Higher Education Monitoring and Analysis Centre. Quality of studies: Stakeholders Approach. Research summary (2014). Available at http://www.mosta.lt/images/leidiniai/Studiju_kokybe_Lietuvoje_suinteresuotu_saliu_poziuris.pdf.

Roehl, A., Reddy, S. L., \& Shannon, G. J. (2013). The flipped classroom: An opportunity to engage millennial students through active learning. Journal of Family and Consumer Sciences, 105(2), 44.

Sajienė, L., \& Tamulienè, R. (2011). Studijų, kaip paslaugos, kokybės vertinimo dimensijų ir kriterijų pagrindimas: atvejo studija (= Justification of Quality Assessment Dimensions and Criteria of Studies as a Service: Case Study). Profesinis rengimas: tyrimai ir realijos, 2011, No. 21, p. 82-93.

Smetona, A. (2012). Studijų terminų žodynas (= Dictionary of Higher Education Terms). Aukštojo mokslo kokybė, 2012, No. 9, p. 191-195.

Stanišauskienė, V. (2015). Karjeros sprendimus lemiančių veiksnių dinamika kartų kaitos kontekste (= The Dynamics of Factors Determining Career Decisions in the Context of Generation Change). Tiltai, 71(2), 1-20.

Taylor, P. (2014), The Next America: Boomers, Millennials, and the Looming Generational Showdown, Perseus Publishers, New York, NY. 
The Law Amending the Law on Higher Education and Research of the Republic of Lithuania No. XI-242, effective from 1407-2016. Internet access: http://www.lrs.lt.

Toleikis, Š., \& Butvilas, T. (2014). Studentų nuomonès svarba aukštojo mokslo kokybės užtikrinimo procesuose (= The Importance of Students Opinion in the Processes of Quality Assurance in Higher Education). Studies in Modern Society, $5(1)$.

Trakšelys, K., \& Martišauskienė, D. (2016). Švietimo paslaugu kokybė: efektyvumas, rezultatyvumas, prieinamumas (= The Quality of Education Services: Efficiency, Effectiveness, Accessibility). Tiltai, 73(1), 191-206.

Vengrienè, B. (2006). Paslaugų vadyba (= Service Management). Vilnius: Vilniaus universiteto leidykla.

Zhao, Y. (2007). Social studies teachers' perspectives of technology integration. Journal of technology and teacher education, 15(3), 311-333.

Žibėnienè, G., \& Dudaitė, J. (2012). Studijų kokybės samprata: pirmojo kurso studentų požiūris (= Study Quality Concept: The First Course Student Approach). Socialinès inovacijos globaliai plètrai, 1(1), 1098-1111.

Žibènienè, G., \& Targamadzè, V. (2006). Aukštojo mokslo studijų sistemos harmonizavimas Lietuvoje-studiju kokybès tobulinimo prielaida (= Harmonization of Higher Education System in Lithuania - Prerequisite for Quality Improvement of Studies). Aukštojo mokslo kokybė, 2006, No. 3, p. 81-91. 